\title{
Evaluation of the Implementation of the Educational Inclusion of Junior High School Level in Central Java Constructs
}

\author{
Sri Widiastuti \\ Public Administration Doctoral Progam \\ Faculty of Social and Political Science \\ Diponegoro University, Semarang, Indonesia
}

Sri Suwitri

Public Administration Doctoral Progam

Faculty of Social and Political Science

Diponegoro University, Semarang, Indonesia

Y. Warella

Public Administration Doctoral Progam

Faculty of Social and Political Science

Diponegoro University, Semarang, Indonesia

Haryono

Public Administration Doctoral Progam

Faculty of Social and Political Science

Diponegoro University, Semarang, Indonesia

Received: October 12, 2016 Accepted: February 2, 2017 Published: February 6, 2017

doi: 10.5296/jsss.v4i2.10694 URL: http://dx.doi.org/10.5296/jsss.v4i2.10694 


\section{Abstract}

Educational inclusion is one of education placing all of disability learners into regular class. This research aims to explore the implementation of educational inclusion of Junior High School level in Central Java province today and arranging the most effective model for this advantaging of education inclusion for disability learners of Junior High School level in Central Java province. This research uses qualitative method. The result is analyzed by qualitative analysis technique. This result shows that the implementation of educational inclusion of Junior High School level in Central Java hasn't maximally, it because of various things, such as many district/ city haven't implement district head regulation as the basic law of implementation of educational inclusion, in order many supporting components haven't complied, such as curriculum for this learners, facility and infrastructure, the human resource supporting, etc. The development of educational inclusion of Junior High School level in Central Java is implemented by comply a lot of requirements of the implementation of organizing educational inclusion such as mentioning on regulation of Minister of National Education Number 70 in 2009 about educational inclusion, for example: there is a district head regulation as basic law, facility and infrastructure fulfilled, knowledge and teacher skill and so on. The conclusion states that the educational inclusion should be comply all of supporting factors so that the implementation is not only suitable with expectation, but also needing a commitment from all of parties.

Keywords: Development, Implementation, Educational inclusion, Junior high school

\section{Introduction}

Education was one of basic necessity for every human that will be continued forevermore so that they would be more dignities. Through education, they would become the best creature for their self and meaningful for others when they show off as Caliph I the world (Aedy 2009:70). Therefore, the Country has an authority to give educational service having quality for each citizen including for someone whose have disability. Without considering racial, modernity and socio cultural, all of citizens in the world being in agreement that every child have an authority in getting education. In this context, Mialaret (1993:5) imposed to United Nations Educational, Scientific, and Cultural Organization (UNESCO) onto responsible of working arrangement each nations aiming to improve similarity chance into education. One of improvements realized through Dakkar declaration in 2000 by resulting educational concept for all (Educational for all).

Attribution this consensus of Indonesia Government that has arrange planning of PUS implementation program from 2000 to 2015. Annually, the implementation advantaging of educational the whole or Educational For All (EFA) in Indonesia and UNESCO members State always be checked on by UNESCO and this result is reported through Education for All Global Monitoring Report (EFA-GMR). Bases on this scheme of PAUD empowerment and other education, there are 6 targets of PUS as follows: (1) the expansion and restoration all of maintenance and pre-school leaning known as PAUD, prioritized for susceptible children and unlucky child; (2) rendering similar access to all children in completing primary school that has similar quality with other, especially for girls and minority ethnic in 2015; (3) the learning necessities to all community should be provided fairly; (4) the restoration amount 
$50 \%$ on adult indignity level, especially for women, together with access fairly in primary education and continuity for adults; (5) striking disparity gender into primary and middle school levels along with guarantee of equality gender realization in education; and (6) the restoration in aspect relates to educational quality, so that it will impact on learning result that is admitted and gauged.

Bases on 6 targets in PUS, Indonesian government through Ministry of National Education and Cultural priority this target into 6 programs as follows, (1) pre-school learning (PAUD) program, (2) primary education program, (3) life skill education program, (4) equality program, (5) gender prioritizing program, and (6) education quality increasing program. In line with target and program priority in a realization of Dakkar declaration, every country in the world assumes an education as human rights of nations, especially for disability children. It has been stated into constitutional laws chapter 31 article 1 and 2 as follows (1) every nations should get education (2) government operate and implement one national education system, arranged by constitutional laws, along with constitutional laws Number 20 in 2003 about National Education System, Chapter 5 Article 2 directly state that "the nations whose have physical abnormality, emotional, mental, intellectual, or social deserve in getting fancy education". Therefore, the government and other parties should give attention seriously to the education implementation for disability children, in order something expected and dedicated onto revealing Constitutional Laws 1945 aiming to educate nations life will realize well.

The mandate of education right for disability children is also stated into constitutional laws Number 20 in 2003 about National Education System Article 32 stated that: "special education is part of education for learners whose have difficulties category onto participation of learning process because of their physical abnormality, emotional, mental and social or having intelligence potentiate so is special talent". The consistency into Constitutional Laws Number 20 in 2003 is really very meaningful for disability children because it gives forceful basis that they need to get similar chance as well as given for other normal children in education and learning (Efendi, 2006:1).

The productivity of disability children through education have to prioritize becoming one of national education plan in order they will have independency life. It means, they will have more ability in taking an action independently, the persistence in obtaining achievement, able in thinking and taking action rationally, able in control their self, and has a prestige and self confidence. It was hoped that the disability children existence around normal children will not be buried (Efendi, 2006:2). The disability children created by god around the universe couldn't be stated as failure invention. An abnormality condition both of cognitive lack or physical will not be able preventing someone for highest achievement. In reality, they also have incredible potential. A lot of them have gotten successful explore their special skills in order they able to obtain highest achievement more than normal child. While, the disability children right are still marginalized in getting education. For example, Asyhabuddin (2008:406) found that a lot of people whose have different talent physically should be eliminated both of education or working conditions, although both of them that is desired by these groups actually doesn't depend on physical ability.

The similar problem also stated by Purwandari (2009). She states that, the disability children get different manner into educational service, because they are determined has an obstacle 
onto many life dimensions, so that their educational service should be separated from "normal" children condition in order the learning process will not burden. The school for disability children follows specific education model such as segregation model that place them at specific school known as SLB. They separate from their similar age friends because this school has curriculum, learning facility and special teacher, so that they don't get chance in developing their potency optimally. In line with this case, Praptiningrum (2010:33) also added to that unconsciously the education for disability children is adapted base on anomaly will create exclusivism border for them. This will pursues introducing process among normal children with disability children, then will impact on social interaction around community, the disability children become avoiding groups. The community becomes unknown with their social life, while they feel their existence doesn't become part of community life integrally around this environment.

This condition is still far from commitment of Jeneva cohesion like PUS. That means that, it should be get similarity rights such as other children, they also deserve getting similar educational service. Base on this case then appearing the model concept of inclusive education. Through inclusive education, character diversity and students capability will be accommodated wisely by giving them chance for learning. Though, in inclusive education, the differential is determined as learning source, than as problem (Sutrisno, 2012:32). The other is one of international agreement persuade the realization of inclusive education system namely Conventional on the Right of Person with Disabilities and Optional Protocol legalized in March 2007. In the Article 24 of this convention states every country has to implement inclusive education system for every educational level. One of goal is stimulating realization of disability children participation around community life.

The implication of this convention insists Indonesia to participate onto convention implementation that has been agreed. One of implementation of this convention is realized onto regulation of Minister of National Education Number 70 in 2009 about inclusive education for disability learner and has an intelligent potency or special talent becomes formal rule basis for development effort of inclusive education in Indonesia. This regulation consists of complete rules about inclusive education start from planning to execution. The other is this regulation also obligate regional government such as district or city to choose minimal one school that should execute inclusive education. So is, circular publication from director general of education for basic and middle school Minister of National Education No. 380/C.66/MN/2003, in January 202003 about inclusive education states that every district or city in Indonesia is minimally has 4 schools who implement inclusive education include Elementary School, Junior High School, Senior High School and Skill Middle School for every one school.

Through the regulation of Minister of National Education and circular publication have many expectation from inclusive education implementation to the disability children manner. However, the result study of coordination agency of inclusive education in Central Java cooperate with educational agency of Central Java Province estimated from 33.472 disability children that is obtained information about 26.568 (79,37\%) of disability children in Central Java doesn't go to school (Subagyo 2009), while amount $6.904(20,62 \%)$ of disability children has been gone to school. If it is compared with children amount less than 15 years 
old in Central Java reach 8.440 .155 children, the disability amount in Central Java as many as $0,39 \%$. Although this amount is small relatively, their desire in getting education properly hasn't been felt. It is because of their separating at various regions far away from disability children so that they haven't gone to the school.

Subagya (2012:20) stated that their displeasure for going to school is based on many reasons, as follows (1) their house is far from this school, (2) they are refused for getting school at nearest school, and (3) their parents motivation is very low/ shy / hiding. Even though, the data from Education Agency of Central Java province is stated that there are five districts from 35 districts or cities whose haven't have State school for disability, namely (1) Demka District, (2) Klaten District, (3) Magelang District, (4) Wonosobo District, (5) Banyumas District. Therefore, inclusive education without through disability children is very needed for giving easiness way for disability children in getting education properly. One of is realized by joining the disability children at regular school. Therefore, not all of regular school posed an inclusive education existence in Central Java Province who hasn't gotten education service. From 4.540 Junior High School in Central Java, there are only 519 schools is enthusiasm becoming inclusive school, such as 472 schools both of state and private status are mount 47 schools. The distribution of comprehensiveness accepted onto inclusive school able to be seen in the Table 1 below.

Table 1. The amount students of inclusive education school bases on mentally classification in Central Java Province

\begin{tabular}{llll}
\hline No. & Classifications & Mentally Classifications & Amount \\
\hline 1. & A & Blind Mentally & 75 \\
2. & B & Deaf Mentally & 97 \\
3. & C & Minor Mentally Retarded & 913 \\
4. & C1 & Middle Mentally Retarded & 137 \\
5. & D & The Minor of Physical Orthopedic Mentally & 146 \\
6. & D & The Middle of Physical Orthopedic Mentally & 30 \\
7. & E & Abnormally Attitude Mental & 156 \\
8. & F & Dumb Mentally & 74 \\
9. & G & Multiple Growth Mentally & 38 \\
10. & H & Hyperactive & 547 \\
11. & I & (ADHD /Attention Deficit Hyperactivity Disorder) & 75 \\
12. & J & Indigo & 14 \\
13. & K & Slowly Learning & 4.501 \\
14. & Ats & Autism & 101 \\
Total & & & $\mathbf{6 0 . 9 0 4}$ \\
\hline
\end{tabular}

Source: Educational Agency of Central Java Province in 2014.

In reality, education for disability children in Indonesia as far as caused by three kinds of educational institution, namely school for disability that locally known as (SLB), the primary level of school for disability and integrated education. It as the eldest of special education 
institution, providing children with similarity of gender and mentally classification so that there is a classification of school for disability as follows blind mentally, deaf mentally, mentally retarded, physical orthopedic mentally, abnormally attitude mental and multiple growth mentally of schools for disabilities. While, the primary level of school for disability provides various kinds of disabilities children in order these will be consist of various kinds of mentally conditions too. As regards to integrated education is a regular school provides disability children base on similarities curriculum, teacher, learning facility and learning process. Today it is still providing blind mentally, but this development is still lack of expectation because many general schools are still objectionable providing the disability children.

Generally, the location of school for disability located at capital district. Whereas this mentally condition separate almost in all districts both of district or sub-district, not only separate at capital district. This impact is majority of disability children especially with low economy condition of their parents doesn't able send to school because of far location from home; while if they will send to nearest elementary school, this school will not provide because they doesn't able giving service. The other is, possibility they will be provide at nearest elementary school, but because of the nothingness special service for them, so that they possibility will be downgrade and finally despairing school. This problem will impact on failure program of mandatory education because the completing program of nine mandatory educations hasn't reached education rights for disability children.

Base on this fact the educational institution of Central Java Province in 2010 has proclaimed block grand blazing for 160 schools of inclusive education coordination. It is done for reducing disability children who hasn't sent to school annually (Subagya, 2012:20). Socialization and technical guidelines of inclusive education have been done repeatedly, while this implementation result of inclusive education in these 160 schools hasn't been optimally (Trimo, 2012:225). Base on this data it can be concluded that the complying of education right for disability children is only confined as expectation.

The non optimal condition base on Ishartiwi (2010) was caused by the implementation of inclusive education today hasn't been harmonious with national school system tending to apply standard service system (the similar manner for each human and completing study by standardize national standard). Relates to their condition whose have various limited and learning necessity, the implementation of inclusive education at school needs curriculum modification, learning strategy, assessment system of learning result and school management which is suitable with necessity service for disability children. So that, the implementation of inclusive education need to be studied and found the model of inclusive education that is suitable with own characteristic of disability children in Central Java Province. Because of the educational levels are various, the development model of inclusive education for disability children in Central Java Province is focused on Junior High School level. It refers to curriculum complexities that are accepted by them along with physic susceptible condition will influence other competence development. The other, in Central Java the amount of disability children classify into elementary school age until 2014 reach 81 thousands. From this amount, there are only 6.904 disability children who able to take education at school and 74.096 others haven't served their education right (Widodo, 2014). 


\section{MInstitute Macrothink $_{\text {Ins }}$}

This condition mention into Constitutional Laws 1945 Chapter 31 Article 1 and Constitutional Laws Number 2 in 1989 about National Education System Chapter III Article 5 who are stated that every nations of State have similarity chance in getting education, including for disability children. Even though, the Constitutional Laws of Indonesian Republic Number 20 in 2003 about National Education System gives diversity into educational service for disability children. in the Chapter 15 explanation about specific education stated that specific education is an education to all learners both of mentally disorder or learners whose have incredible intelligence that is coordinated inclusively or a unit specific education into basis and middle educational levels. The aim of this school for disability children is an education given to all of nation State whose have physical or mental disorder in order they will able to socialize with others communities.

Therefore, this problem is proper and important to be studied deeply through article entitled "EVALUATION OF THE IMPLEMENTATION OF THE EDUCATIONAL INCLUSION OF JUNIOR HIGH SCHOOL LEVEL IN CENTRAL JAVA”.

\section{Research Method}

This research kind is qualitative research. The subject research is teacher and student in State Junior High School 1 Kedung Jepara, State Junior High School 1 Pageruyung Kendal, State Junior High School 3 Kesesi Pekalongan, and State Junior High School Mojosongo Boyolali, Central Java, Indonesia. The technique of data collecting that is applied is interviewing, observation and documentation. The technique of data validity applies triangulation data technique, while the technique analysis applies data analysis step, data reduction, arrangement into a unity data, categorization, validity data checking and data analysis base on theory or concept applied.

\section{Result and Discussion}

The regulation of National Education Minister known as (Permendiknas) Number 70 in 2009 about inclusive education for learners whose have disorder and intelligence potency or marvelous talent are stated that meant as inclusive education is educational organizing system who give chance to all learners stated above to take participation in education or learning formally together with other learners generally. The meaning of education mentions into National Education Minister giving detail explanation about who is someone should be placed into inclusive education. The detail given by government is able to be understood as a policy that has been prospered with condition in Indonesia, in order government need to give similar chance to all learners including normal condition, having disorder and having special intelligence or special talent in joining education. Therefore, government start to change educational model as far as separating normal learner place at regular school, while the learners with marvelous intelligence and special talent place at acceleration school, also for learners with mentally disorder place at school for disability children knows as SLB.

Base on these meanings generally the inclusive education concepts are stated similar. Inclusive education means an education arranged and adapted with all of learners necessity, both of learners with normal condition or learners with mentally disorder. Every of them get similar educational service without differentiating each other. Someone who called as disability children used to call as special children. The disability children are one of other 
word to replace special children word indicate a specific disorder. Another word also usually used to indicate them is impairment, disability and handicap.

The disability children have different characteristic between one with other. Delphie (2006:1-3) stated that in Indonesia the disability children whose had mentally growth and had been given service including: impairment mentally, blind mentally, deaf mentally, dumb mentally, mentally retarded, physical orthopedic mentally, abnormally attitude mental, autism, hyperactive (attention deficit disorder with hyperactive), learning disability or specific learning disability, and multi handicapped and developmentally disabled children. In the Regulation of National Education Minister of Indonesian Republic Number 70 in 2009, children that become victim of drugs abusing and other addictive essence so are whose have talent or marvelous intelligence also categorized as disability children. Therefore, it not only accommodated children whose have mentally disorder, inclusive education is also accommodate them in order they will able to learn together in a one class.

Kustawan (2012, 23-24), the disability children consist of permanent disorder who need specific education known as PK and temporary disorder who need specific education service known as LPK. The disability children permanently are someone who gets learning obstacle and growth obstacle because of naturally or self source (for example children whose have obstacle or vision disorder, hearing disorder, thinking disorder and others). While disability children temporary is someone who gets learning obstacle and growth obstacle because of out of self. For example children who come from poor family, children come from isolating community and so on. The inclusive education coordination in Central Java had progressed since 2010 by pioneer 160 inclusive schools from Elementary, Junior High School, and Senior High School these are separated at Boyolali District, Jepara District, Pekalongan District and many district or other City. Every pioneer school gets Decision Letter knows as SK appointment of performing inclusive education school. Contrary there are also schools that coordinate inclusive education without followed with Decision Letter because they want to fulfill real necessities.

Inclusive education was education system coordination who gives chance to all learners with mentally disorder and having marvelous intelligence or special talent to take a part in education or learning activity together with other students normally (Chapter 1, The Regulation of Minster of National Education Number 70 in 2009 about inclusive education for learners whose have condition stated above). This program aiming to give children quality educational chance base on necessity and ability so does realization of educational coordination that appreciates diversity and nondiscrimination for all children.

This regulation mentioned above is one of public policy issued by government to solve inclusive education problem formally. Based on Woll (1966); Easton (1969) public policy were various activities of government to solve problem around community both of directly or through many institution that influence community life (government intervention form). That means that the Regulation of Minister of National Education is part of government activity to solve problem of disability learners around community, through educational institution that influence their social life. While the influence of government act is as follows:

1) There is a policy created by politician, government employee or other who aiming to utilize public empowerment to influence community life. 


\section{Macrothink}

2) There is an output policy, where policy applied in this level demand government to implement regulation, budgeting, personality and creating regulation into program that will influence community life.

3) There is a policy impact which comes from policy choice influencing community life.

Whereas the function of inclusive education was all of children got a chance and similar access in getting quality educational service and based on their necessity, also creating conducive educational environment for all children in developing their potency optimally (Kustawan, 2012).

Even though, government has been issued the Regulation of Minister of National Education Number 70 in 2009 about inclusive education as long as explain above, in reality the implementation of inclusive education hasn't been implemented maximally. There are disability children haven't gotten their right in getting education properly base on their talent. It is because of many factors, where every region has different characteristic base on problem face. Nugroho (2009; 494-496) stated that public policy into Constitutional Laws or Local Regulation was kinds of public policy that need clearness policy or regulation of its implementation. The policy operates directly are as follows Presidential decision, Presidential instruction, Decision of the Minister, Decision of District Head, and so on. Base on this statement it shows clearness that reality the Regulation of Minister of National Education as one of public policy part into Minister Regulation needs clearness policy or regulation of implementation because they can't directly operating. There isn't clearness policy in every district or city having a form of regional regulation issued by District Head of Government duty about inclusive education impact on the obstacle of this implementation, so that there are many disability children who haven't gotten their right in getting education properly base on their talent.

These conditions above also happen at State Junior High School 1 Jepara, State Junior High School 1 Pageruyung Kendal, State Junior High School 3 Kesesi Pekalongan, and State Junior High School Mojosongo Boyolali, Central Java, Indonesia. The implementation of inclusive education at these four schools are different depend on condition classification and necessity reality. Here is the differentiating of implementation at these four schools as follows: 


\section{Ml Macrothink}

Table 2. The implementation of inclusive education state junior high school 1 Jepara, State Junior High School 1 Pageruyung Kendal, State Junior High School 3 Kesesi Pekalongan, and State Junior High School Mojosongo Boyolali, Central Java, Indonesia

\begin{tabular}{|c|c|c|c|c|c|}
\hline No & $\begin{array}{lr}8 & \text { Standards } \\
\text { National Procedure }\end{array}$ & $\begin{array}{lr}\text { Junior } & \text { High } \\
\text { School } & 1 \\
\text { Kedung } & \\
\text { Jepara } & \\
\end{array}$ & $\begin{array}{l}\text { Junior High } \\
\text { School } 1 \\
\text { Pageruyung } \\
\text { Kendal }\end{array}$ & \begin{tabular}{lr|} 
Junior & High \\
School & 3 \\
Kesesi & \\
Pekalongan & \\
\end{tabular} & $\begin{array}{l}\text { Junior High School } 4 \\
\text { Mojosongo Boyolali }\end{array}$ \\
\hline 1. & $\begin{array}{l}\text { The Standard of } \\
\text { Alumnus } \\
\text { Competence }\end{array}$ & $\begin{array}{lr}\text { There isn't } \\
\text { SKL for } \\
\text { disability } \\
\text { children }\end{array}$ & $\begin{array}{lr}\text { There isn't } \\
\text { SKL for } \\
\text { disability } \\
\text { children }\end{array}$ & $\begin{array}{l}\text { There isn't } \\
\text { SKL for } \\
\text { disability } \\
\text { children }\end{array}$ & $\begin{array}{l}\text { Similar SKL with regular } \\
\text { students }\end{array}$ \\
\hline 2. & $\begin{array}{l}\text { The Subject } \\
\text { Standard }\end{array}$ & $\begin{array}{l}\text { Similar with } \\
\text { standard } \\
\text { content of } \\
\text { regular student }\end{array}$ & $\begin{array}{l}\text { Similar with } \\
\text { standard } \\
\text { content of } \\
\text { regular student }\end{array}$ & $\begin{array}{l}\text { Similar with } \\
\text { standard } \\
\text { content of } \\
\text { regular } \\
\text { student }\end{array}$ & $\begin{array}{l}\text { Similar with standard content of } \\
\text { regular student }\end{array}$ \\
\hline 3. & $\begin{array}{l}\text { The } \\
\text { Standard }\end{array}$ & $\begin{array}{l}\text { Similar with } \\
\text { standard } \\
\text { process of } \\
\text { regular student }\end{array}$ & $\begin{array}{l}\text { Similar with } \\
\text { standard } \\
\text { process of } \\
\text { regular student }\end{array}$ & $\begin{array}{l}\text { Similar with } \\
\text { standard } \\
\text { process of } \\
\text { regular } \\
\text { student }\end{array}$ & Adapted with their necessity \\
\hline 4. & $\begin{array}{l}\text { The Standard of } \\
\text { Teacher and Its } \\
\text { Academy }\end{array}$ & $\begin{array}{l}\text { There is } 2 \\
\text { teachers have } \\
\text { gotten } \\
\text { socialization } \\
\text { and } \\
\text { educational } \\
\text { training about } \\
\text { inclusive } \\
\text { education }\end{array}$ & $\begin{array}{l}\text { There is } 1 \\
\text { teachers have } \\
\text { gotten } \\
\text { socialization } \\
\text { and } \\
\text { educational } \\
\text { training about } \\
\text { inclusive } \\
\text { education }\end{array}$ & $\begin{array}{l}\text { There is } 2 \\
\text { teachers have } \\
\text { gotten } \\
\text { socialization } \\
\text { and } \\
\text { educational } \\
\text { training about } \\
\text { inclusive } \\
\text { education }\end{array}$ & $\begin{array}{l}\text { The majority teachers have } \\
\text { gotten socialization and } \\
\text { educational training about } \\
\text { inclusive education }\end{array}$ \\
\hline 5. & $\begin{array}{l}\text { The Standard of } \\
\text { Facility and } \\
\text { Infrastructure }\end{array}$ & $\begin{array}{l}\text { Hasn't } \\
\text { fulfilled }\end{array}$ & Hasn't fulfilled & $\begin{array}{l}\text { Hasn't } \\
\text { fulfilled }\end{array}$ & Adapted with their necessity \\
\hline 6. & $\begin{array}{l}\text { The Standard of } \\
\text { Management }\end{array}$ & $\begin{array}{l}\text { There isn't } \\
\text { specific } \\
\text { standard of } \\
\text { management }\end{array}$ & $\begin{array}{l}\text { There isn't } \\
\text { specific } \\
\text { standard of } \\
\text { management }\end{array}$ & $\begin{array}{l}\text { There isn't } \\
\text { specific } \\
\text { standard of } \\
\text { management }\end{array}$ & $\begin{array}{l}\text { There isn't specific standard of } \\
\text { management }\end{array}$ \\
\hline 7. & $\begin{array}{l}\text { The Standard of } \\
\text { Administration }\end{array}$ & $\begin{array}{l}\text { There isn't } \\
\text { standard of } \\
\text { administration }\end{array}$ & $\begin{array}{l}\text { Provisioning } \\
\text { social devotion } \\
\text { in a week }\end{array}$ & $\begin{array}{l}\text { There isn't } \\
\text { standard of } \\
\text { administratio }\end{array}$ & $\begin{array}{l}\text { There is an administration } \\
\text { standard }\end{array}$ \\
\hline
\end{tabular}




\begin{tabular}{|l|l|l|l|l|l|}
\hline 8. & $\begin{array}{l}\text { The Standard of } \\
\text { Assessment }\end{array}$ & $\begin{array}{l}\text { There isn't } \\
\text { standard of } \\
\text { assessment }\end{array}$ & $\begin{array}{l}\text { There isn't } \\
\text { standard of } \\
\text { specific } \\
\text { assessment }\end{array}$ & $\begin{array}{l}\text { There isn't } \\
\text { standard of } \\
\text { specific } \\
\text { assessment }\end{array}$ & adjusted base on their necessity \\
\hline
\end{tabular}

There isn't maximal implementation of the Regulation of Minister of National Education Number 70 in 2009 such as explaining above is part of public policy based on Edward (1980:10:11) able to be influenced by many factors, namely: (1)communication, (2)resources, (3)disposition, and (4)bureaucracy structure. Among these factors shows interaction and will influence to the implementation. This model able to be presented in the picture below:

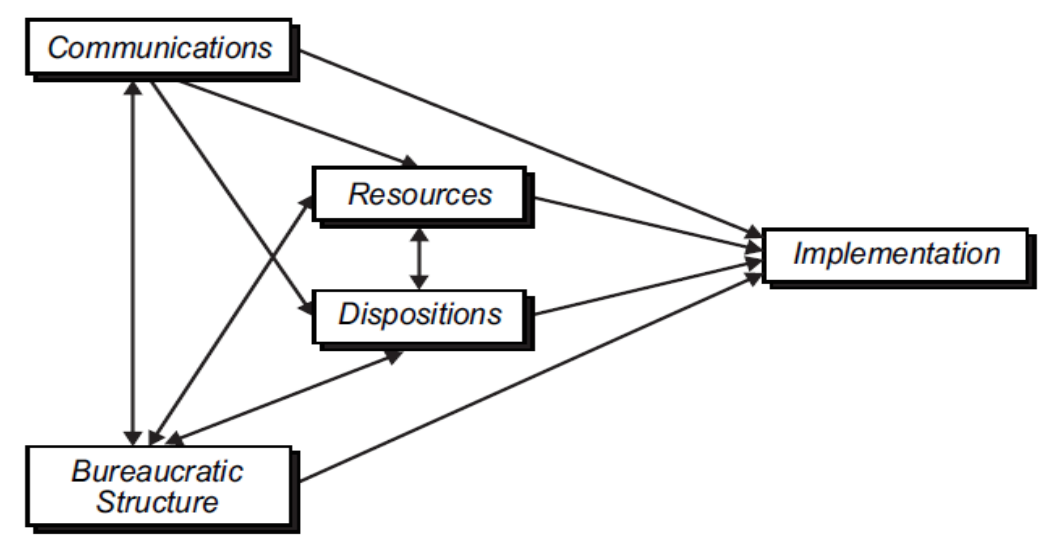

Figure 1. Direct and Indirect Impact on Implementation George Edwards (1980)

\section{Communication}

It is a process of communication conveying from communicator to communicant. Other while, communication policy meant a process of information policy conveying from policy maker to policy executor (Widodo, 2011:97). Then, Widodo (2011:97) added that information needed to be conveyed to policy executor in order they able to understand what do the meaning, goal, way, target group of policy so that they able to prepare what something related to policy implementation in order this would create effective process and conform with this policy goal.

Communication into policy implementation includes many important dimensions namely information transformation (transmission), clearness information (clarify) and consistency information (consistency). The transformation dimension intends information is not only conveyed to policy executor but also to target group and relating participant. The clearness dimension intends clearness information and easy to be understood, the other is to obey interpretation mistake of policy executor, target group or relating participant into policy implementation, while the dimension consistency intends information that is conveyed should be consistent in order it will not impact on confusion of policy executor, target group or 
relating participant.

One of communication that able to be done into implementation of inclusive education is socialization to all teachers at this school. The fact improves that not all of teacher have participate socialization about inclusive education, the consequence not all of teacher have sufficient understanding about inclusive education. Though there is a statement as part as teacher state that the disability children existence at school will impact on new problem such as negative stigma from community who state if placing disability children is part of school for disability children, then their existence will increase teacher burden in learning activity, and so on. The lack socialization as positive communication act of government makes the implementation of public policy can't reach this goal.

\section{Resources}

Resources have important role into policy implementation. Edward (1980) stated that however the clearness and consistency regulations and accurate conveying of this regulations, if the policy executor who have authority to execute policy doesn't has resource properly in implementing policy effectively, the policy implementation will not be effective. The resources meaning in this context relates to various resources who able to be utilized to support the successful of policy implementation. These include human resource, budgeting, facility, information and authority. The classifications of these resources are presented as follows:

a. The human resource (staff); the policy implementation will not succeed without supporting from human resource bases on quality and quantity. These qualities resources relate to skill, dedication, professionalism and competency in every field, while these quantities relate to what do human resource amount is sufficient representing all of target group. Human resource very influence on implementation successful, because without them this policy implementation will proceed slowly. In this case teacher as main resource into implementation of inclusive education take a main role and becoming the first. Because they are main role on fulfillment necessity for disability children students. Teachers should be given the best understanding about inclusive education in order they will understand their duties. There is only a little teacher that has understood this task.

b. Budgeting; in the policy implementation, budgeting relate to fund sufficiency or investment for a program so is policy to guarantee this policy implementation. Without enough fund supporting, the policy will not proceed effectively in reaching goal and target. Government should fund specifically for inclusive education funding, base on the research result shows that the school chosen as inclusive education coordinating only receive an operational fund only in a year. The amount is variation, there isn't funding continuity in order the school is difficult in fulfill their necessity. For example, because of limited fund, school is unable giving hearing aid for disability children who can't hear clearly, etc.

c. Facility; facility or infrastructures are one of factor influence into policy implementation. The proper facility supplying, such as building, soil and office equipment will support the successful of implementation program or policy.

d. Information and authority; information also become important factor into policy implementation, especially for relevant information and sufficient relate to how to implement 


\section{Macrothink

a policy. While the authority takes an important role to convince and guarantee that policy implemented is suitable with our wished.

\section{Disposition}

The tendency behavior or characteristic of policy executor takes an important role to realize policy implementation that is suitable with goal or target. The important character should be owned by policy executor include honesty and the high commitment. Honesty point at executor is to stay on program goal whose has been decided, while the high commitment of policy executor will make them always being enthusiastic on taking a task, authority, function and liability base on regulation established.

The behavior of policy executor will very influence into policy implementation. If the executor has good behavior then they will able to implement a policy well like what does it want by policy maker, vice versa if their behavior doesn't support then the implementation will not proceed well.

\section{Bureaucracy Structure}

Organization structure has influence significantly on policy implementation. The aspect of organization structure covers two things namely mechanism and bureaucracy structure. The first aspect is mechanism that in a policy implementation usually has been created standard operation procedure abbreviated as SOP. It becomes guidance for every executor in taking an action in order in this implementation is parallel with a goal and policy target. The second aspect is bureaucracy structure, it is too long and fragmented that will inclined debilitating a control and causing bureaucracy procedure are difficult and complex then will impact on organization activity inflexibility.

Here is a lot of profile of disability students at many Junior High Schools explained above:

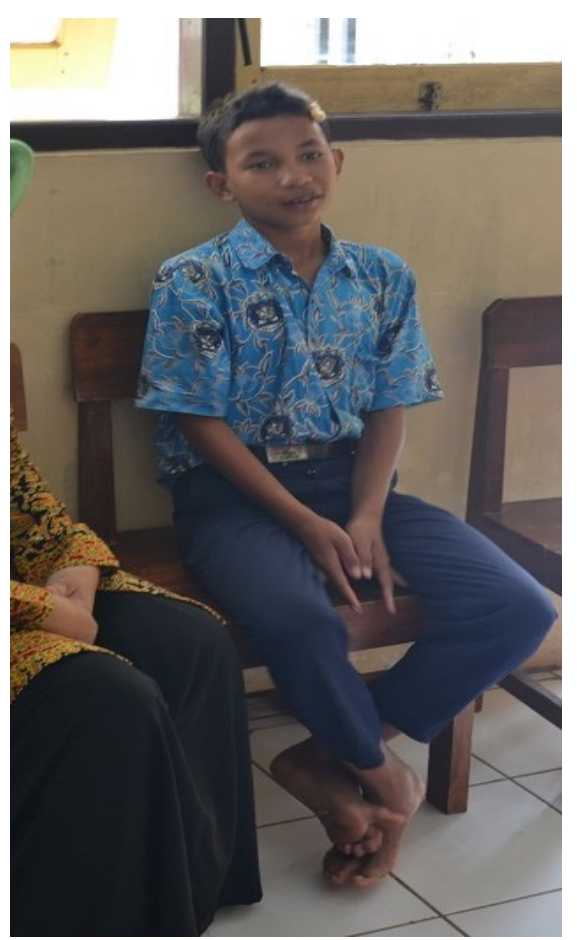

The Profile of disability student at Junior High School 1 Pageruyung 


\section{Macrothink}

ISSN 2329-9150

2017, Vol. 4, No. 2

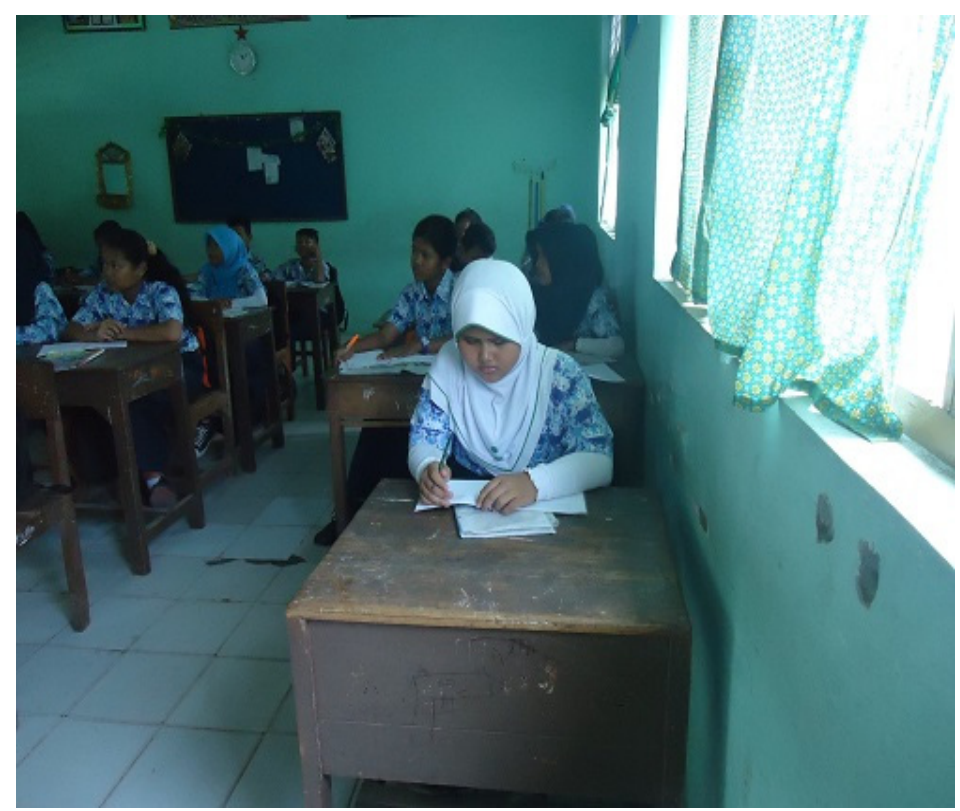

The Profile of disability student at Junior High School 4 Mojosongo

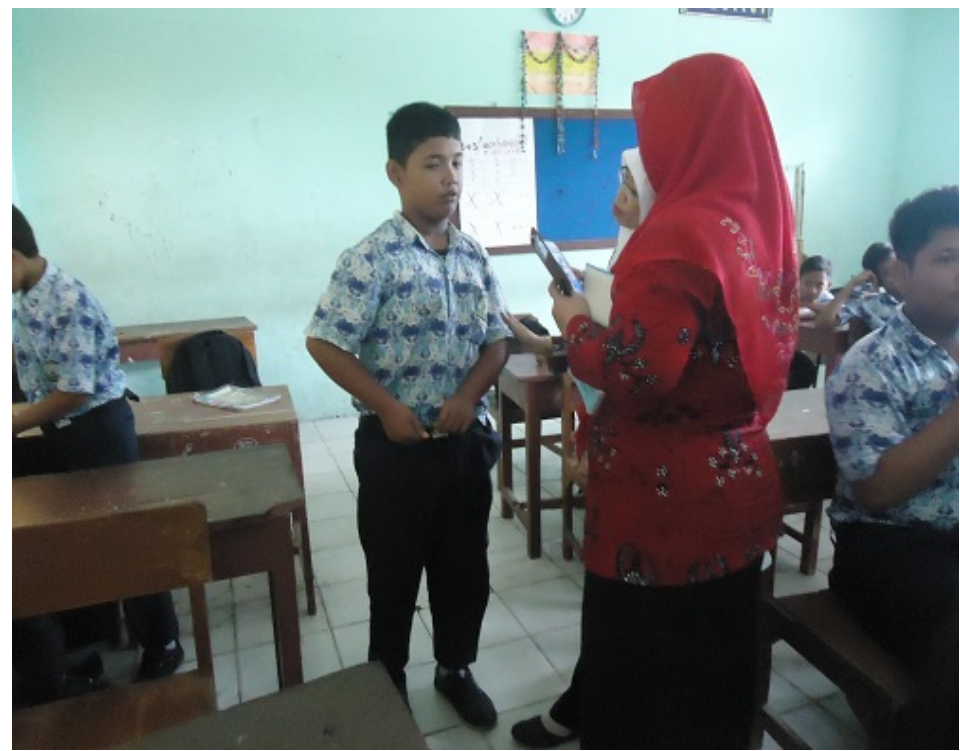

The Profile of disability student at Junior High School 4 Mojosongo 


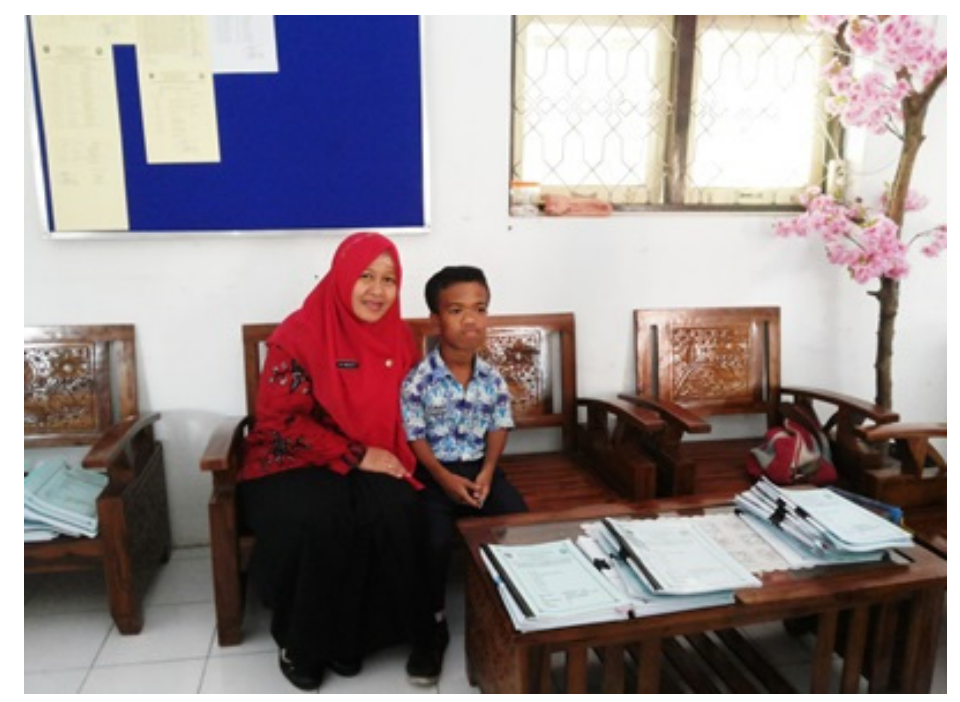

The Profile of disability student at Junior High School 4 Mojosongo

The evaluation implementation of inclusive education for disability children at Junior High School level in Central Java Province is able to be done through evaluation of educational management. Base on Regulation of Minister of National Education Number 70 in 2009 the function management of inclusive education include: planning, organizing, directing, coordination, controlling and evaluation. The school management of inclusive education coordinator gives full authority to school party to plans, coordinate, direct, control and evaluate components of inclusive education relates it. This component includes: students management, curriculum management, learning management, assessment management, teacher management, staff management, facility and infrastructure managements, administration and human resource managements.

Here is the school management of inclusive education coordinator at these four schools as follows:

1) The Management of Inclusive Education at Junior High School 1 Kedung Jepara

This school has permission as school coordinator of inclusive education from Educational Institution, Young and Athletic of Jepara District, but base on new Headmaster decision states that this school doesn't coordinating it because of unpreparedness school management. In order this school management uses school management generally.

2) The management of inclusive education at Junior High School 1 Pageruyung Kendal

This school isn't one of school chosen to coordinating inclusive education, but because of necessities reality, such as the disability children existence register then the Headmaster policy states that they will receive these students in order they are able to fulfill educational necessity to all students especially for disability children. Here is the form management of inclusive education applied by Headmaster from Junior High School 1 Pageruyung ] 


\begin{tabular}{|c|c|}
\hline Planning & $\begin{array}{l}\text { In the beginning of new student registration there is a } \\
\text { different registration system, such as if there is a regular } \\
\text { student is based on their graduation score at Elementary } \\
\text { School. While if there is a disability student done through } \\
\text { direct interviewing with Headmaster. It is done among } \\
\text { student accompanied by their parents. The Headmaster will } \\
\text { identify the student lack, including sluggish learner or } \\
\text { physical anomaly. If they classify into easy level while they } \\
\text { will be accepted but if they category into heavy level they } \\
\text { will be recommended to join at School for Disability } \\
\text { Children known as SLB. }\end{array}$ \\
\hline Organizing & $\begin{array}{l}\text { In the next process the Headmaster will discuss with } \\
\text { teachers about the existence of disability children relate to } \\
\text { their administration, class placement and othe component. }\end{array}$ \\
\hline Directing & $\begin{array}{l}\text { The headmaster will give guidance about the existence of } \\
\text { disability children, how this curriculum, syllabus, RPP, the } \\
\text { learning way, material and this assessment. This school } \\
\text { doesn't has permission as the coordinator of inclusive } \\
\text { education, then the teachers limited knowledge relate to } \\
\text { inclusive education finally it is decided that curriculum, } \\
\text { syllabus, RPP, media, material and assessment are similar } \\
\text { with regular students. Only these teachers are hoped giving } \\
\text { more attention to disability students, especially in the } \\
\text { learning process. }\end{array}$ \\
\hline Coordinating & $\begin{array}{l}\text { The coordination is done every time between Headmaster, } \\
\text { teacher, committee and the disability children parents. This } \\
\text { is done aiming to fulfill their necessity well. For example in } \\
\text { helping their administration process, the Headmaster } \\
\text { instruct pursuing activity namely Jum'at Bersedekah } \\
\text { (Friday Charity) for all citizens around Junior High School } \\
1 \text { Pageruyung, collecting fund on Friday, where the fund } \\
\text { collecting will be given to students need, not only for } \\
\text { disability students but also regular students come from poor } \\
\text { family. This fund will be given into pocket money weekly. } \\
\text { The committee role and society into administration at } \\
\text { school also coordinated by Headmaster. }\end{array}$ \\
\hline Controlling & $\begin{array}{l}\text { The control system is done through involving all of } \\
\text { community around this School, both of teachers, students } \\
\text { and employee. }\end{array}$ \\
\hline Evaluation & The assessment is done by all of teachers and trustee class. \\
\hline
\end{tabular}


3) Management of inclusive education at Junior High School 3 Kesesi Pekalongan

This school is one of Junior High School who gets permission of inclusive education coordination from Educational and Cultural Institution of Pekalongan District. Here is the implementation management of inclusive education at Junior High School 3 Kesesi Pekalongan:

\begin{tabular}{|c|c|}
\hline Planning & $\begin{array}{l}\text { In beginning step, when the registration of new students, the } \\
\text { school separate among regular students and disability } \\
\text { students. The regular students are based on the graduation } \\
\text { score of Elementary school, while the disability students are } \\
\text { based on interviewing process with school party. The } \\
\text { majority accepted is disability students relate to sluggish } \\
\text { learning. Then in the beginning of learning process all of } \\
\text { students will participate into psychological test celebrated } \\
\text { by school collaborated with certain psychological } \\
\text { institution. Base on this test result then it will be able to be } \\
\text { detected the students necessity base on physical condition } \\
\text { and their physic. }\end{array}$ \\
\hline Organizing & $\begin{array}{l}\text { After this test the students are classified shaken up. This is } \\
\text { aiming to minimize an impression of classification between } \\
\text { disability students and regular students. In this school a lot } \\
\text { of teachers have participated socialization about inclusive } \\
\text { education, but only several person. for teacher who have } \\
\text { been knowing this knowledge then they will not bring up } \\
\text { this problem in controlling disability children, vice vase for } \\
\text { teacher who hasn't been knowing will tendency equalizing } \\
\text { them with regular students. The most curricula applied is } \\
\text { similar among disability student and regular student, only } \\
\text { this teacher whose has knowledge about inclusive education } \\
\text { will distinguish the learning method applied, including into } \\
\text { assessment process. }\end{array}$ \\
\hline Directing & $\begin{array}{l}\text { The headmaster will give guidance in the first learning } \\
\text { process in order this directing of inclusive education able to } \\
\text { be done well through involving all of school component and } \\
\text { community in all things. }\end{array}$ \\
\hline Coordination & $\begin{array}{l}\text { The coordination is done to fulfill necessity of inclusive } \\
\text { education, including administration, facility, infrastructure, } \\
\text { and so on. }\end{array}$ \\
\hline Controlling & $\begin{array}{l}\text { The controlling is done by all of school committee and } \\
\text { community around it. The most of disability students } \\
\text { classify into sluggish learning category usually coming from }\end{array}$ \\
\hline
\end{tabular}




\begin{tabular}{|l|l|}
\hline & $\begin{array}{l}\text { broken home family and poor family so that the controlling } \\
\text { factor from parents to their children are very limited even } \\
\text { not yet. }\end{array}$ \\
\hline Evaluation & The assessment is done by teachers. \\
\hline
\end{tabular}

4) The management of inclusive education at Junior High School 4 Mojosongo Boyolali

The implementation of inclusive education at this school is done base on decision letter of Boyolali District Head. Here is the implementation function of inclusive educational management that is applied:

\begin{tabular}{|l|l|}
\hline Planning & $\begin{array}{l}\text { There is a different process of new student registration } \\
\text { among regular students and disability students. The } \\
\text { regular students base on graduation score from } \\
\text { Elementary school, while the disability student base on } \\
\text { interviewing process with committee arranged by this } \\
\text { school. }\end{array}$ \\
\hline Organizing & $\begin{array}{l}\text { The Headmaster asks the GBK to able coordinate all of } \\
\text { things relate to necessity of disability student. It is start } \\
\text { from class classification, curriculum, syllabus, RPP, } \\
\text { learning material, learning media including assessment. } \\
\text { This school uses curriculum modified, it is } \\
\text { accommodated with necessity of disability student. It } \\
\text { includes additional course for disability student classify } \\
\text { into sluggish learning category. }\end{array}$ \\
\hline Directing & $\begin{array}{l}\text { The Headmaster guides the disability students in getting } \\
\text { manner base on their necessity in order their education } \\
\text { right will be fulfilled. }\end{array}$ \\
\hline Coordination & $\begin{array}{l}\text { The coordination is done by involving teacher, student, } \\
\text { parents, school committee and community. }\end{array}$ \\
\hline Controlling & This controlling is done accordingly. \\
\hline This assessment is done by relating teacher.
\end{tabular}

Inclusive education requires the school party should conform to necessity demanding of each student, not the student who conforms to this school system. The opinion about education that should conform to the student condition is very relate to differentiate exist of each student. The older opinion stated that students should conform to education and learning process in the classroom gradually has to change (Lindgren 1967: 503-504). For this reason, the school that coordinates inclusive education ideally also has to utilize management of inclusive education to conform in demanding of student necessity. 


\section{Macrothink}

\section{Conclusion and Suggestion}

Base on the result and discussion above it can be concluded as follows

1) The implementation of inclusive education for disability children in Junior High School level in Central Java Province hasn't been done maximally, it is because of various things such as not all of District or City desires to issue regulation specifically arranging the implementation of inclusive education, the school unpreparedness as inclusive education coordinator and there isn't implementation model of inclusive education effectively and efficiently in order in can be become as role model.

2) The evaluation of inclusive education for disability children in Junior High School level in Central Java Province hasn't been maximally. Both on planning, organizing, directing, coordinating, controlling, evaluation.

\section{Suggestion}

\section{The suggestions able to be given bases on conclusion above are:}

1) For the Government Province and District/ City: they need a regulation specifically arrange the implementation of inclusive education.

2) For the coordinating school of inclusive education: they need preparation in many aspects relate to implementation of inclusive education.

3) For the parents of disability students: they have to be taken part actively into directing, guiding and monitoring their children.

4) For community: they should participate actively into supporting implementation of inclusive education.

\section{References}

Aedy, H. H. (2009). Karya Agung Sang Guru Sejati (The Genuine Teacher by Agung). Bandung: Alfa Beta.

Anderson, J. (1978). Public Policy Making. New York: Praeger.

Asyhabuddin. (2008). "Difabilitas dan Pendidikan Inklusi: Kemungkinannya di STAIN (Disability and Inclusive Education: Posiibility in STAIN).

Pendidikan Inklusi bagi Peserta Didik yang Memiliki Kelainan dan Memiliki Potensi Kecerdasan dan/atau Bakat Istimewa (Inclusive Education for Disability Learners whose Have Physical Anomaly and have Intelligence Potency or Marvelous Talent).

\section{Copyright Disclaimer}

Copyright for this article is retained by the author(s), with first publication rights granted to the journal.

This is an open-access article distributed under the terms and conditions of the Creative Commons Attribution license (http://creativecommons.org/licenses/by/3.0/). 